\title{
Treason, Terrorism and United States' Citizens: Sanctioned Assassinations?
}

\author{
Michial Michalovich ${ }^{2}$ and ${ }^{*}$ Chandrika Kelso ${ }^{1}$ \\ ${ }^{1}$ School of Professional Studies, National University, USA \\ ${ }^{2}$ Colonel-USMC (Ret), Mission Assurance Director, MCB CAMPEN, USA
}

Submission: November 21, 2016; Published: January 24, 2017

*Corresponding author: Chandrika Kelso, School of Professional Studies, National University, 11255 North Torrey Pines Road, La Jolla, CA 92037, USA, Tel: 858642 8671; Email: ckelso@nu.edu

Abstract

The Constitution of the United States of America has specific instructions on what needs to be done for the country to participate in a war and also to limit the power of the President to get the country involved in hostilities or to curtail the President from declaring an individual an enemy of the state leading to imposition of death. Congress passed a resolution in 2002 which allowed the President to use force against terror groups and countries which supported them. The operation to eliminate Anwar al-Awlaki became public after he was killed by a targeted drone strike. This paper has two objectives: one is to gain a better understanding of the U.S. law concerning the potential assassination of U.S. citizens accused of terror activity; and to identify and explore the constitutional gaps in the current policy so as to make recommendations that will align policy with law.

Abbreviations: ACLU: American Civil Liberties Union; FBI: Federal Bureau of Investigation; DHS: Department of Homeland Security; DOD: Department of Defense; AQAP: Al Queda in the Arabian Peninsula; INA: Immigration and Nationality Act

\section{Introduction}

Radical Islamists have been at war with the U.S. since the 1980s however, the American public didn't begin to take the threat seriously until September 11th, 2001 [1]. This resulted in the passage of a number of laws that bestowed previously unseen powers on our executive branch. These actions have brought together such diverse groups as the American Civil Liberties Union (ACLU) and tea party activists to oppose certain actions that the U.S. Government has sanctioned [2,3]. The actions of 9/11 changed the tapestry of the United States in many ways. However, though this act was one of terror, there does not seem to be a universally acceptable definition of terrorism. Different definitions exist across the federal, international and research communities. Title 22 of the U.S. Code, Section 2656f(d) defines terrorism as premeditated, politically motivated violence perpetrated against noncombatant targets by sub national groups or clandestine agents, usually intended to influence an audience. The Federal Bureau of Investigation (FBI) defines terrorism as "the unlawful use of force or violence against persons or property to intimidate or coerce a government, the civilian population, or any segment thereof, in furtherance of political or social objectives. This definition of terrorism is based upon the agency's general functions under 28 CFR $\S 0.85$ [4]. 18 U.S.C. § 2331 defines terrorism as either international or domestic. International Terrorism activities have the following three characteristics: Involve violent acts or acts dangerous to human life that violate federal or state law; appear to be intended

i. to intimidate or coerce a civilian population;

ii. to influence the policy of a government by intimidation or coercion; or

iii. to affect the conduct of a government by mass destruction, assassination, or kidnapping; and Occur primarily outside the territorial jurisdiction of the U.S., or transcend national boundaries in terms of the means by which they are accomplished, the persons they appear intended to intimidate or coerce, or the locale in which their perpetrators operate or seek asylum. Domestic terrorism involves activities committed within the United States. FISA defines "international terrorism" in a nearly identical way, replacing "primarily" outside the U.S. with "totally" outside the U.S. 50 U.S.C. $§ 1801$ (c) $[4,5]$.

The Department of Homeland Security (DHS), echoing its mission, emphasizes critical infrastructure" and focuses on "mass destruction. The Department of Defense (DOD) places more emphasis on the threat as opposed to the actual act of violence, and it, unlike the others, specifically cites religious 
aims as a rationale [6]. Modern terrorism represents a mix of cultural, religious, economic and political causes coming from the radicalized society. United States Government has conducted operations to eliminate citizens who have aligned themselves with terrorist organizations without consideration of their due process rights. This type of action seems to be in direct contradiction of the language and intent of the United States Constitution, Article II-section 2 and Article III, the $5^{\text {th }}$ thru $9^{\text {th }}$ and $14^{\text {th }}$ Amendments. These discuss citizens' fundamental protection of maintaining their life from arbitrary actions of individuals in the government and where the federal government's responsibilities lie concerning these issues. In his Georgetown University address, Justice Brennan noted that the crucial liberties embodied in the Bill of Rights are so central to our national identity that we cannot imagine any definition of "liberty" without them [6-8].

With ever expanding technology and the difficulty in keeping what an individual or a group would consider vital information secure, we have become more and more secretive as a country and as a government. Our history has shown us that the opposite is actually more effective given the numerous examples from the former presidents like Nixon, Regan, Clinton, Bush and our current president. The fifth and fourteenth amendments to the constitution each have a due process clause. The Fifth Amendment due process clause prohibits the federal government from depriving any person of "life, liberty, or property without due process of law." The fourteenth amendment extended that prohibition to the states. The Supreme Court has held that the due process clauses ban government procedures the justices deem unfair. Thus the court has said that the due process clause of the fourteenth amendment requires states to allow an accused person to have a defense attorney, to allow an accused person to respond to accusations, and so forth. Legal scholars say that such cases are examples of "procedural due process." The court also uses the substantive due process doctrine to justify voiding any state or federal law the justices think has no possible "rational basis" $[9,10]$.

\section{Discussion}

When U.S. citizens, by their own choice, become part of a foreign terror group as former $\mathrm{Al}$ Qaeda leader Anwar al-Awlaki chose to do, they can become specific targets of the United States' government and can find themselves being placed on "kill lists". In September, 2011, al-Awlaki was targeted and killed in Yemen by a Hellfire Missile fired from a U.S. drone. The operation and details of the process did not become public record until the questioning of former CIA Director John Bremer during his confirmation hearing before the Senate Intelligence Committee [11]. The $5^{\text {th }}$ Amendment to the U.S. Constitution states: "No person shall be held to answer for a capital, or otherwise infamous crime, unless on a presentment or indictment of a Grand Jury, except in cases arising in the land or naval forces, or in the Militia, when in actual service in time of War or public danger; nor shall any person be subject for the same offence to be twice put in jeopardy of life or limb; nor shall be compelled in any criminal case to be a witness against himself, nor be deprived of life, liberty, or property, without due process of law; nor shall private property be taken for public use, without just compensation."

Additionally, the $14^{\text {th }}$ Amendment, section 1 states, "All persons born or naturalized in the United States, and subject to the jurisdiction thereof, are citizens of the United States and of the State wherein they reside. No State shall make or enforce any law which shall abridge the privileges or immunities of citizens of the United States; nor shall any State deprive any person of life, liberty, or property, without due process of law; nor deny to any person within its jurisdiction the equal protection of the laws" [12]. If you are a citizen of this country, you have to be charged with a crime, and found guilty in a court prior to being executed. These rights have been challenged at different times and in numerous ways since 1791, but federal courts and the U.S. Supreme Court have been very consistent on a literal interpretation for this law. This is why we need a specific and clear process for stripping a citizen who leaves the country and joins an enemy of the U.S. Additionally, in our fight against terror networks; we need to develop a process for targeting and killing terrorists outside the traditional battle field. The Constitution, as drafted in 1787, and ratified in 1791, talked about citizens of the United States and citizens of individual states. In 1868, The $14^{\text {th }}$ Amendment was written to codify the rights of newly freed slaves and give them "full person" status and full rights of a U.S. citizen.

The regulations in the law for citizenship flow out of these two ideas: If a person is born in the U.S., or goes through the process and becomes a naturalized citizen, they have all the rights afforded them under the Constitution and other US public laws. The laws regulating rescinding citizenship from an individual belong to the U.S. State Department. These portions of the law say that an individual will remain a citizen unless he/she does one of the following:

i. Obtaining naturalization in a foreign state upon one's own application after the age of 18 (Sec. 349 (a) (1) INA).

ii. Taking an oath, affirmation or other formal declaration of allegiance to a foreign state or its political subdivisions after the age of 18 (Sec. 349 (a) (2) INA).

iii. Entering or serving in the armed forces of a foreign state engaged in hostilities against the United States or serving as a commissioned or non-commissioned officer in the armed forces of a foreign state (Sec. 349 (a) (3) INA).

iv. Accepting employment with a foreign government after the age of 18 if (a) one has the nationality of that foreign state or (b) an oath or declaration of allegiance is required in accepting the position (Sec. 349 (a) (4) INA); formally renouncing U.S. nationality before a U.S. diplomatic or consular officer outside the United States (sec. 349 (a) (5) INA). 
v. Formally renouncing U.S. nationality within the United States (The Department of Homeland Security is responsible for implementing this section of the law) (Sec. 349 (a) (6) INA).

vi. Conviction for an act of treason against the Government of the United States or for attempting to force to overthrow the Government of the United States (Sec. 349 (a) (7) INA).

Additionally, there must be a hearing at the Department of State to determine if the individual meets one of more of the criteria [12]. However, it appears that there was no defined process to give individuals like Anwar al-Awlaki their due process rights or to strip them of their citizenship. Anwar al-Awlaki was born in New Mexico, but his father returned the family to his birthplace of Yemen after completion of his studies. While in Yemen, the young al-Awlaki studied the Koran and became interested in the fighting of the Mujahedeen in Afghanistan. Al-Awlaki returned to the United States as a college student at Colorado State University, then San Diego State University for a master's degree and finally George Washington University for a doctorate. "During his doctoral studies, Anwar al-Awlaki spent one of his summers while in Afghanistan, fighting with the mujahedin" [3].While in the US, al- Awlaki had contact with Khalid al-Midhar and Nawaf Al-Hazmi who were two of the 9/11 hijackers.

The two men followed him when he moved from San Diego to the DC area, and they considered him their "spiritual advisor." Anwar al-Awlaki left the United States in 2002 for England and in 2004, settled in Yemen. Upon returning, he began to affiliate himself with Al Queda in the Arabian Peninsula (AQAP) which was influential in organizing attacks against the US. Although al Awlaki had done many things in violation of INA regulations to have his citizenship revoked, he had not publically given up his citizenship, nor had it been taken away from him at the time of his killing by drone strike. The ACLU filed an unsuccessful suit on behalf of al-Awlaki's family against the U.S. Government and the CIA over his death [11].

Section 349(a)(5) of the Immigration and Nationality Act (INA) (8 U.S.C. 1481(a)(5)) is the section of law governing the right of a United States citizen to renounce abroad his or her U.S. citizenship. The renunciation of U.S. citizenship does not allow persons to avoid possible prosecution for crimes which they may have committed in the United States, or escape the repayment of financial obligations, including child support payments, previously incurred in the United States or incurred as United States citizens abroad [13]. Anwar-al-Awlaki did not pursue this option of renunciation of his U.S. citizenship. Thus, Anwar al Awlaki, on orders from the Executive Branch of the U.S. Government, a naturalized U.S. citizen was targeted to be killed by using a drone with a missile. This was done without either stripping him of his citizenship or going through the process of a capital crime trial. At the least, one could only hope that a. All citizens of the United States must be afforded the rights bestowed on them by Articles II and III of the Constitution and the Bill of Rights;

b. The U.S. government should revoke the citizenship of individuals suspected and convicted of treason;

c. Adhering to the established criteria in the Constitution for dealing with citizens accused or convicted of treason will continue to enhance the U.S. image in the global arena as a nation that respects, supports and protects its citizens.

According to the Constitution (Article 3, Section 3 and the $5^{\text {th }}$ Amendment), the courts were given the sole authority over life and death matters as it pertained to citizens actions when it involves treason. The President is granted the power and authority of the commander-in-chief, however, the President is required to get the advice and consent of congress to wage war as a safeguard because the founders understood the corrupting influence of power. They saw how easy it would be to eliminate political foes if ansitting president were to declare an individual an enemy of the state in which he could then order them executed. In our constitutional republic, one of the founding principles is that we would have a federal government whose actions would be defined as being open, transparent and accountable to its citizens. That is why the constitution was carefully written having an executive branch, with the President of the United States given limited power and the Judicial Branch and the courts system which were given the power to make life and death decisions pertaining to its citizens. This resolution has allowed for multiple definitions on how to prosecute operations against terror groups by different parts of the government [14].

"In Cramer v. United States (1945), the Supreme Court held that a specific intent of adherence to the enemy, and therefore to harm the United States is necessary, rather than the simple rendition of aid. Further, the majority came close to holding that such adherence requires proof, not just of an act that on its face is "commonplace" (such as a meeting) but a manifestly treasonable overt act, evidenced by the testimony of at least two witnesses. But in Haupt v. United States (1947)-the Court's first affirmation of a treason conviction-the Court effectively relaxed Cramer's standard of proof by holding that the testimony of two witnesses to overt acts might be supported by other evidence as to the accused's treasonable intent, including out-of-court confessions and admissions. In Kawakita v. United States (1952), the Supreme Court held that dual citizenship does not diminish a citizen's allegiance to the United States, and, in a treason prosecution, whether someone intends to renounce American citizenship hinges on particular facts and may be a question for a jury" [15].

\section{Conclusion}

There are a number of difficulties with the current U.S. policy regarding terrorism. The first is that there is no established process in place to strip citizenship from a naturally born or 
naturalized citizen. The second is because there is no consistent definition for terrorism the response to terrorist acts and actions will either be to use the military or law enforcement. The third is that the fear that the September 11, 2001 terror attacks a need for security in the minds of U.S. citizens. That need lessoned the country's concern when the President ordered the assassination of a citizen. Based on the need for more defined clarity concerning what would be proper actions by the United States' government against its own citizens who wage war against America, possible outcomes could be to propose that Congress pass specific legislation to address the issue. The following should be done:

i. The U.S. Code should be amended to outline a process to revoke citizenship of those accused of terrorism and its related plots.

ii. If the United States is going to strip a citizen of his/her citizenship, it should be a public process that should involve the federal courts system.

iii. If the case involves highly classified information, the FISA courts could be used.

Therefore, research in this area should focus on changes to the United States code and developing the processes for implementation. Amending the U.S. Code requires congressional action which would require bi-partisan support. Additionally, due to the recent process of self-radicalization of U.S. citizens using various means, code changes should be supported by changes in/to the Patriot Act. It is with regret that we accept it is not within the scope of this paper to delve deeper into the myriad challenges encompassing citizenship revocation cases, but it is our hope that we have provided enough fodder for thought to embark on such an academic and legal excavation.

\section{References}

1. Thomas H Kean, Lee H Hamilton (2004) National Commission on Terrorist Attacks upon the United States. The 9/11 Commission report, USA.

2. Timothy Sandefur (2007) In defense of substantive due process, or the promise of lawful rule. Harvard Journal of Law \& Public Policy 35(1).

3. Scott Shane (2015) The lessons of Anwar al-Awlaki. The New York Times Magazine, USA.

4. National Institute of Justice-NIJ (2007) Terrorism, USA.

5. Federal Bureau of Investigation-FBI (2016) Definitions of terrorism in US Code, USA.

6. Department of Homeland Security (2016) Countering violent extremism, USA.

7. Department of Defense (DOD) (2016) Dictionary of Military and associated terms. Joint Publication, USA.

8. David C Rapoport (2001) Current history: Four waves of rebel terror and September 11. Anthropoetics-The Journal of Generative Anthropology 8(1).

9. Carl von Clausewitz (1976) On war. Princeton University Press, USA.

10. US Marine Corps (1997) War fighting. Marine Corps Doctrinal Publication 1(MCDP1). USA

11. Avery Plaw (2008) Targeting Terrorists: A License to Kill? Ash gate Publications, UK.

12. The National Historical Publications and Records Commission (2016) Editorial note: The Consular Convention of 1788. Princeton University Press 1958, USA, p. 67-92.

13. US Department of State, Bureau of Consular Affairs (2016) Renunciation of US nationality abroad: The immigration \& nationality act. USA.

14. The Judicial Learning Center (2015) Article III and the courts. USA.

15. The Heritage Guide to the constitution: Treason (2012) USA.

\section{Your next submission with Juniper Publishers will reach you the below assets}

- Quality Editorial service

- Swift Peer Review

- Reprints availability

- E-prints Service

- Manuscript Podcast for convenient understanding

- Global attainment for your research

- Manuscript accessibility in different formats ( Pdf, E-pub, Full Text, Audio)

- Unceasing customer service

Track the below URL for one-step submission https://juniperpublishers.com/online-submission.php 